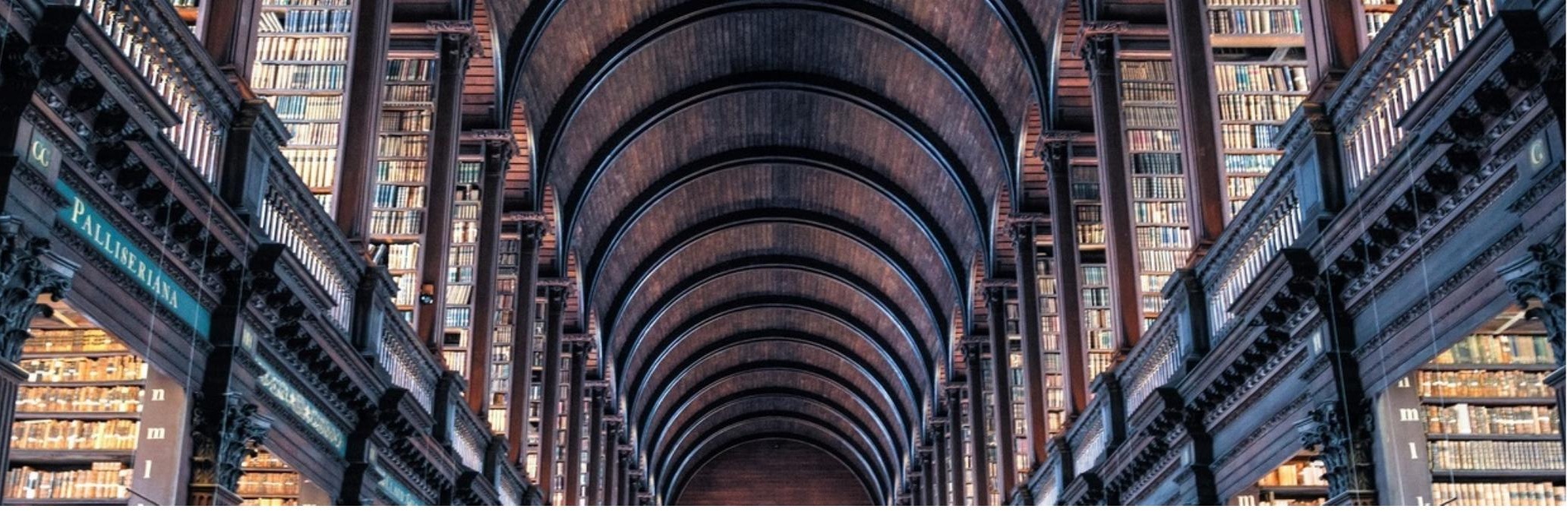

\title{
Editorial Volume 8, Issue 2
}

$\begin{aligned} \text { Authors: } & \text { Silke Masullo } \\ \text { Submitted: } & \text { 3. May } 2021 \\ \text { Published: } & \text { 3. May } 2021 \\ \text { Volume: } & 8 \\ \text { Issue: } & 2 \\ \text { Affiliation: } & \text { Josha Journal, Freiburg, Germany } \\ \text { Languages: } & \text { English } \\ \text { Keywords: } & \text { Editorial, JOSHA Journal, } 2021 \text { Volume 8, Issue } 2 \\ \text { Categories: } & \text { News and Views } \\ \text { DOI: } & 10.17160 / \text { josha.8.2.757 }\end{aligned}$

Abstract:

Dear JOSHA readers, In this bi-monthly issue we present you with a diverse selection of articles. The Journal would like to call your attention to the 2021 Demetrios Prizes, which will be awarded again this year! We would also like to remind you that you can support us with a small donation. http://joshajournal.org/en/donate Visit our social media \#joshajournal and get to know us from the Instagram gallery and the Facebook wall. Remember that you can comment on the articles and also provide your star ranking. 


\section{Editorial}

Volume 8, Issue 2

The current volume again features the full range of the Josha Journal. Follow us from India to Kosovo and to Buenos Aires. And from human prehistory to modern research. A focus is again on medicine and here on topics ranging from cancer research to various implications of the Covid pandemic.

The Journal would like to call your attention to the 2021 Demetrios Prizes, which will be awarded again this year! This initiative is made possible by the International Academy of Sciences, Humanities and Arts (IASHA e.V.) and the BioThera Roland-Mertelsmann Foundation. For the categories Bachelor, Master and Doctor Thesis we will award three prizes in the fall of 2021 of $500 €$ each. For your chance to win, submit your thesis until August $31^{\text {st }} 2021$ !

Now we hope you enjoy reading the journal.

Dr. Stephan Seiler

Vice President

International Academy of Sciences, Humanities and Arts

Volume 8, Issue 1

Jörg Friedrich: Der Preis des wissenschaftlichen Publizierens - The Price of scientific publishing

Ezequiel Arrieta, Facundo Monaco: Pucho vs. Vapo - Smoking vs. Vaping

Donart Koci: Palliative care for elderly People

Avani Sapre: Three - Dimensional Culture For Continuous Long Term Live Cell Imaging

Monica Hickson: The other C Word - Covid - Dealing With the Lack of Closure

Johanna Patton: Varanasi - The Together Project

Flaka Xërxa Beqiri, Vlora Navakazi, Bardha Meka: The Journey of Kosovo Modernism: A Process of Metamorphosis

Matthias Glaubrecht: Das Ende der Evolution - The End of Evolution

Nina Raad: ATP rapidly and reversibly induces Calcium Influx in MCF-7 Breast Cancer Cells

Linus Akudolu: An Ethical Concern on Gender-Based Violence against Women and Girls in Africa during COVID-19 Lockdown 